\title{
Preliminary 3-D geological models of Los Humeros and Acoculco geothermal fields (Mexico) - H2020 GEMex Project
}

\author{
Philippe Calcagno ${ }^{1}$, Gwladys Evanno ${ }^{1}$, Eugenio Trumpy ${ }^{2}$, Luis Carlos Gutiérrez-Negrín ${ }^{3}$, José Luis Macías ${ }^{4}$, \\ Gerardo Carrasco-Núñez ${ }^{5}$, and Domenico Liotta ${ }^{6}$ \\ ${ }^{1}$ Geothermal Division, BRGM, Orléans, 45060 cedex 2, France \\ ${ }^{2}$ Institute of Geosciences and Earth Resources, CNR, Pisa, 56124, Italy \\ ${ }^{3}$ Grupo Directivo, CeMIEGeo, Morelia, Michoacán, 58090, Mexico \\ ${ }^{4}$ Instituto de Geofísica, Universidad Nacional Autónoma de México, Campus Morelia, Michoacán, 58190, Mexico \\ ${ }^{5}$ Centro de Geociencias, Universidad Nacional Autónoma de México, Campus UNAM Juriquilla, Queretaro, 76230, Mexico \\ ${ }^{6}$ Department of Earth and Geo-Environmental Sciences, Bari University, Bari, 70125, Italy
}

Correspondence: Philippe Calcagno (p.calcagno@brgm.fr)

Received: 29 May 2018 - Revised: 16 October 2018 - Accepted: 22 October 2018 - Published: 13 November 2018

\begin{abstract}
As part of the GEMex Project, an on-going European-Mexican effort to develop geothermal energy from non-conventional sources, preliminary geological models have been constructed for two sites located in the easternmost region of the Trans-Mexican Volcanic Belt. The first site, Los Humeros, which has produced geothermal electricity for decades, is investigated for its probable superhot geothermal resources. The second site, Acoculco, is a less known but promising area where application of an Enhanced Geothermal System is being studied. In order to have a coherent geological interpretation of both sites, preliminary 3-D models were constructed in a collaborative manner by European and Mexican partners. These models are based on data available at the start of the project, including geological maps, cross-sections and well logs. The data were mainly provided by the Comisión Federal de Electricidad (CFE), and the Mexican Centre for Innovation in Geothermal Energy (CeMIE-Geo consortium). A regional model was developed for each site and an additional local model was constructed for Los Humeros. The preliminary geological models serve as a framework for GEMex work on heat-transport and fluidflow simulations; they will be updated and refined during the project, using new data and interpretations from ongoing and future field work on geology, geophysics, and geochemistry.
\end{abstract}

\section{Introduction}

The exploitation of a geothermal resource depends on the ability of carrying the energy from the underground to the surface. One of the most common ways is to access a naturally convective hydrothermal fluid, but such a vector is not always available. This is why methods are developed to make geothermal energy usable without the direct availability of a geothermal fluid. The term Enhanced Geothermal Systems (EGS) refers to techniques that allow retrieving energy when favourable conditions are not naturally met (Olasolo et al., 2016). In some cases, the available energy is highly concentrated in the near underground: here, SuperHot Geothermal Systems (SHGS) are defined by a high temperature, above $350^{\circ} \mathrm{C}$ and by specific properties of the fluid, requiring advanced techniques for drilling and exploitation (Elders et al., 2014; Reinsch et al., 2017).

An understanding of the edifice of geothermal systems, in terms of temperature variations and of the relationships between geological structures and fluid pathways, is necessary for determining the occurrence and location of exploitable geothermal resources (Cloetingh et al., 2010; Calcagno et al., 2014). One of the main difficulties lies in combining the available data to understand the geological context. 3-D geological modelling (Houlding, 1994; Mallet, 2002; Wu et al., 2005) allows merging such data in the same space to produce a consistent interpretation. In addition, a geomodel provides the geolocated geometry of a geological object that can be used as input for subsequent numerical modelling, such as 


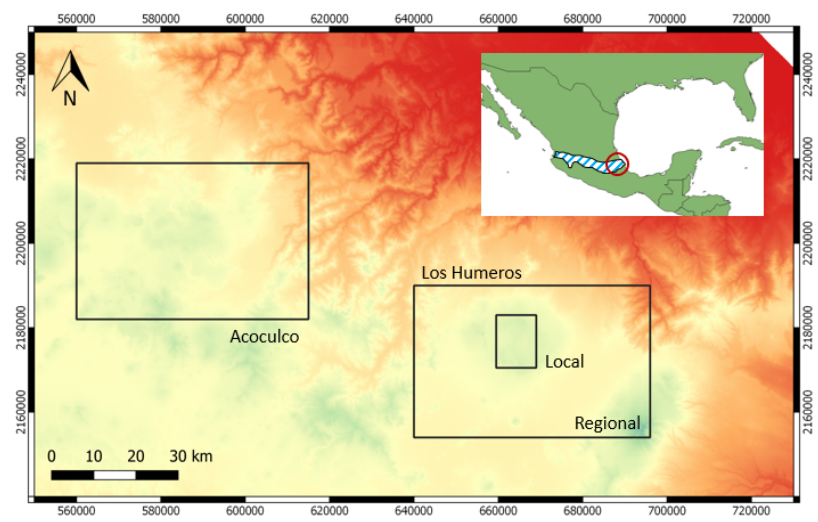

Figure 1. The investigated sites, Los Humeros and Acoculco, are located east of Mexico City in the Trans-Mexican Volcanic Belt (TMVB, dashed blue area). Acoculco is modelled at regional scale. Los Humeros is modelled at regional and local scales. Area locations are shown on the Digital Elevation Model SRTM 90m. Coordinate system is WGS84/UTM zone $14 \mathrm{~N}$.

temperature and fluid-flow simulation (Blöcher et al., 2010; Schilling et al., 2013).

This approach is applied to research into EGS and SHGS occurrences in the GEMex project ${ }^{1}$, to develop coherent, comprehensive and reliable 3 -D geomodels that (a) are based on data from various disciplines, (b) serve as reference for further computations and simulations, and (c) help to understand the geothermal systems. To this end, preliminary 3-D models were developed for providing a coherent geological interpretation based on the existing state of the art. Two sites were used by GEMex as representative examples of SHGS (Los Humeros) and EGS (Acoculco) (Fig. 1). Both are located in the eastern part of the Trans-Mexican Volcanic Belt (TMVB) running roughly east-west across central Mexico.

\section{Geological and geothermal setting}

Los Humeros and Acoculco belong to the Trans-Mexican Volcanic Belt (TMVB). This major structure runs across central Mexico, where volcanic activity is reported to have started about $16 \mathrm{Ma}$ ago (Ferrari et al., 1999) and contin-

\footnotetext{
${ }^{1}$ GEMex is a European Union "Horizon 2020" research and innovation project (2016-2020) of 24 European partners collaborating with a nine-partner Mexican consortium. The aim of GEMex is the design of reliable, efficient, and replicable methods for developing Enhanced Geothermal Systems (EGS) and SuperHot Geothermal Systems (SHGS). To this end, GEMex uses a comprehensive range of investigations: study of the geological and geothermal context, detection of deep structures, reservoir characterization, and conceptual design of EGS and SHGS development including a socio-economic approach. More information on project structure and content in Jolie et al. (2018) and http://www.gemex-h2020.eu (last access: 22 October 2018).
}

ues today with several active volcanoes. These young volcanic processes make the TMVB a favourable area for active geothermal fields.

\subsection{Los Humeros}

The Los Humeros Volcanic Complex has been studied and exploited for decades (López-Hernández, 1995). CarrascoNúñez et al. (2017a, b, 2018) have recently produced a revised geological map of the Los Humeros area and a reappraisal of its geologic evolution (Fig. 2). Geomorphologically, the Los Humeros volcanic system is an 18 to $20 \mathrm{~km}$ wide circular caldera structure, with an inner and younger subordinate 5-8 km-wide oval caldera (Los Potreros). Geologically, it is a Pleistocene basalt-andesite-rhyolite system with geothermal activity currently being exploited. It is the northernmost volcano of the Serdán-Oriental Basin (SOB), which lies west of the andesitic stratovolcanoes forming the Citlaltépetl-Cofre de Perote volcanic range. The Los Humeros volcanic complex is characterized by a multistage formation, with at least two major episodes of caldera collapse: the Los Humeros caldera and the Los Potreros caldera formed at 460 and $100 \mathrm{ka}$, respectively (Ferriz and Mahood, 1984). However, recent work based on modern geochronological dating methods (U/Th and precise ${ }^{40} \mathrm{Ar} /{ }^{39} \mathrm{Ar}$ ) has revealed a much younger formation age of these calderas at 165 (Los Humeros) and 70 ka (Los Potreros) (Carrasco-Núñez et al., 2018).

The Los Humeros area is a major geothermal target in the TMVB. Understanding the structure of this volcanic complex and its influence on the occurrence of thermal anomalies and hydrothermal fluids is important for understanding the interplay between the volcano-tectonic setting and the characteristics of local geothermal resources.

In Los Humeros, geothermal energy has been exploited since the 1990s by the Comisión Federal de Electricidad (CFE), when the first $5 \mathrm{MW}$ power unit started operating. Electricity is currently produced from twenty-five production wells, mainly located in the Los Potreros caldera domain, producing around 6 million tons of steam per year to feed six power units with a combined installed capacity of $94 \mathrm{MW}$ (Romo-Jones et al., 2018). Sixteen wells were available for the preliminary study described here (Fig. 2). The maximum temperature measured at approximately $2.5 \mathrm{~km}$ depth is around $400{ }^{\circ} \mathrm{C}$, but no geothermal fluid at this temperature is currently being exploited by CFE. Los Humeros today is a conventional hydrothermal system, with locally super-hot fluids underground. The aim of GEMex is to obtain a better understanding of the geothermal field, especially of the location of these super-hot fluids and the way to exploit them.

The geothermal target is mostly located in the pre-caldera volcanic rocks (mainly andesite), but it is also expected to find superhot fluids in portions of the underlying carbonaterock basement that may present secondary permeability. In Los Humeros, the ignimbrites forming the caldera seem to 

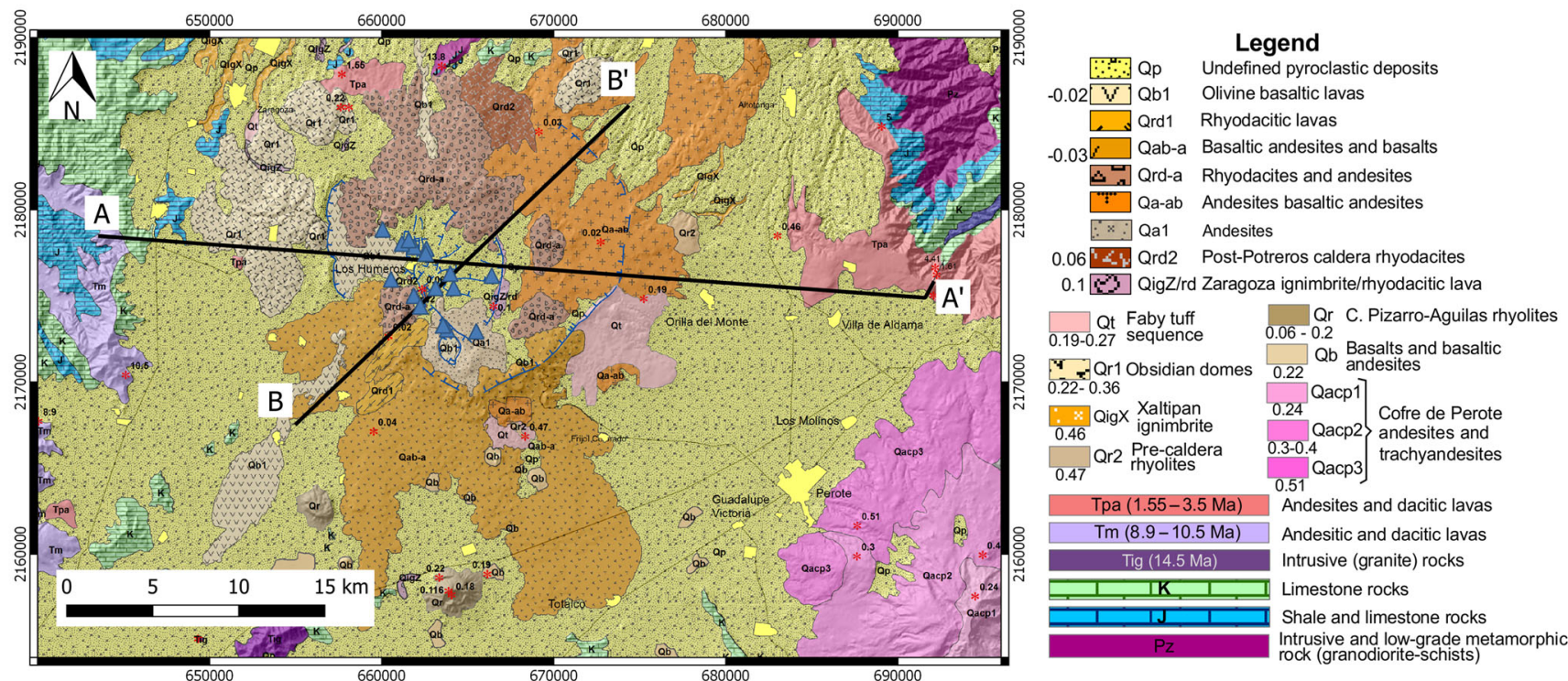

Figure 2. Geological map of Los Humeros adapted from Carrasco-Núñez et al. (2017b). Blue triangles: location of the sixteen wells used for modelling. AA': Carrasco-Núñez et al. (2017b) cross-section trace, BB': Norini et al. (2015) cross-section trace (see Fig. 8). Coordinate system is WGS84/UTM zone $14 \mathrm{~N}$.

act as a seal-rock. From a geothermal standpoint, the geological formations of the Los Humeros area consist of four groups. In addition to the basement (first group), it is important to separate the volcanic formations into three distinct groups: pre-caldera, caldera, and post-caldera. For a more detailed interpretation of the geothermal system, these four can be split into nine units: basement, basal pre-caldera, intermediate pre-caldera, upper pre-caldera, Los Humeros caldera, intermediate caldera, Los Potreros caldera, post-caldera, and undefined pyroclastic deposits.

Figure 3 presents the four groups used for modelling Los Humeros at regional scale, and the nine units used at local scale.

\subsection{Acoculco}

The Pliocene-Pleistocene volcanic complex of Acoculco is far less known than Los Humeros. Two exploratory boreholes were drilled. The temperature is around $300^{\circ} \mathrm{C}$ at $2 \mathrm{~km}$ depth, but no exploitable fluid has been discovered (LorenzoPulido et al., 2010). Preliminary geological studies consider the site a candidate for the application of EGS technology to develop the field (Lorenzo-Pulido et al., 2010; Peiffer et al., 2014, 2015; Garcia-Valles et al., 2015; Canet et al., 2015). According to these studies, the geothermal target is probably located in the basement composed of calcareous, granitic and metamorphic rocks, since the overlying volcanic rocks show intense hydrothermal alteration (López-Hernández et al., 2009; Lorenzo-Pulido et al., 2010; Peiffer et al., 2014; Canet et al., 2015). Avellán et al. (2018a) have produced a geological map of Acoculco (Fig. 4).
The Acoculco area is another caldera complex, but much older than the Los Humeros one. It is located at the intersection of the NE-SW Tenochtitlan-Apan, NWSE Taxco-San Miguel de Allende, and E-W Chapala-Tula fault systems, within a regional extensional regime (GarcíaPalomo et al., 2017). The complex rests upon a basement formed by granite, Cretaceous limestone and marble, the Zacatlan-Chignahuapan basalt plateau and Miocene precaldera domes and lavas (10-3 Ma). The caldera-forming eruption occurred $2.7 \mathrm{Ma}$ ago with an explosive event that dispersed pyroclastic density currents emplacing the Acoculco andesitic ignimbrite with a volume of $\sim 127 \mathrm{~km}^{3}$. Volcanic activity continued with several post-caldera events, and finished around $0.06 \mathrm{Ma}$ with scoria cones and lava flows of basaltic trachyandesite to basaltic andesite (Sosa-Ceballos et al., 2018). Aeromagnetic data show the presence of at least four intrusive bodies at depths of 1 to $>2 \mathrm{~km}$, intruded into the Cretaceous limestone, where granitoid rocks were intersected in the EAC1 and EAC2 exploratory boreholes from $1600 \mathrm{~m}$ down to $2000 \mathrm{~m}$ below ground level. In the EAC1 borehole, the presence of an aplite dyke dated $183 \pm 36 \mathrm{ka}$ suggests that such intrusions are related to recent heat transfer (Avellán et al., 2018b).

No geothermal fluids were identified in the two exploratory wells drilled by the CFE in the 1980s (Fig. 4). However, the high temperatures recorded and the data collected show that a geothermal target may be located in the basement where EGS development is planned. In view of this context, a differentiation of the volcanic rocks is not as critical as at Los Humeros, and the total thickness of this volcanic succession is far less (around $700 \mathrm{~m}$ against over $2000 \mathrm{~m}$ at 


\begin{tabular}{|c|c|c|c|}
\hline Group & Unit & Rock & Age (Ma) \\
\hline \multirow[b]{2}{*}{ G1 Post-caldera } & U1 Undefined pyroclastic & Tuff, pumice and some alluvium & $<0.003$ \\
\hline & U2 Post-caldera & $\begin{array}{l}\text { Rhyodacite, andesite, basaltic andesite, and olivine } \\
\text { basalt lava flows }\end{array}$ & 0.050 to 0.003 \\
\hline \multirow{5}{*}{ G2 Caldera } & \multirow{2}{*}{ U3 Los Potreros caldera } & Rhyodacitic flows & \\
\hline & & Zaragoza ignimbrite & 0.069 \\
\hline & \multirow{2}{*}{ U4 Intermediate caldera } & Faby tuff with andesitic-dacitic lava flows & 0.07 \\
\hline & & Rhyolitic and obsidian domes & 0.074 \\
\hline & U5 Los Humeros caldera & $\begin{array}{l}\text { Mainly composed of Xaltipan ignimbrite with minor } \\
\text { andesitic and rhyolitic lava }\end{array}$ & 0.165 \\
\hline \multirow{3}{*}{ G3 Pre-caldera } & U6 Upper pre-caldera & $\begin{array}{l}\text { Rhyolite, dacite, some andesite and tuff, and minor } \\
\text { basalt }\end{array}$ & 0.693 to 0.155 \\
\hline & U7 Intermediate pre-caldera & $\begin{array}{l}\text { Mainly pyroxene andesite (Teziutlán andesite) with } \\
\text { mafic andesite in the basal part and/or dacite }\end{array}$ & 2.61 to 1.46 \\
\hline & U8 Basal pre-caldera & $\begin{array}{l}\text { Mainly hornblende andesite (Alseseca andesite and } \\
\text { Cerro Grande) and subordinate dacite }\end{array}$ & 10.5 to 8.9 \\
\hline \multirow{4}{*}{ G4 Basement } & \multirow{4}{*}{ U9 Basement } & Middle Miocene granite & 15.12 \\
\hline & & Cretacic limestone, shale and minor flint & $\sim 140$ \\
\hline & & Jurassic limestone and shale & $\sim 190$ \\
\hline & & Paleozoic granite and schist (Teziutlán Massif) & $>251$ \\
\hline
\end{tabular}

Figure 3. Description of the geological formations modelled in Los Humeros at regional scale gathered into four groups and nine units.

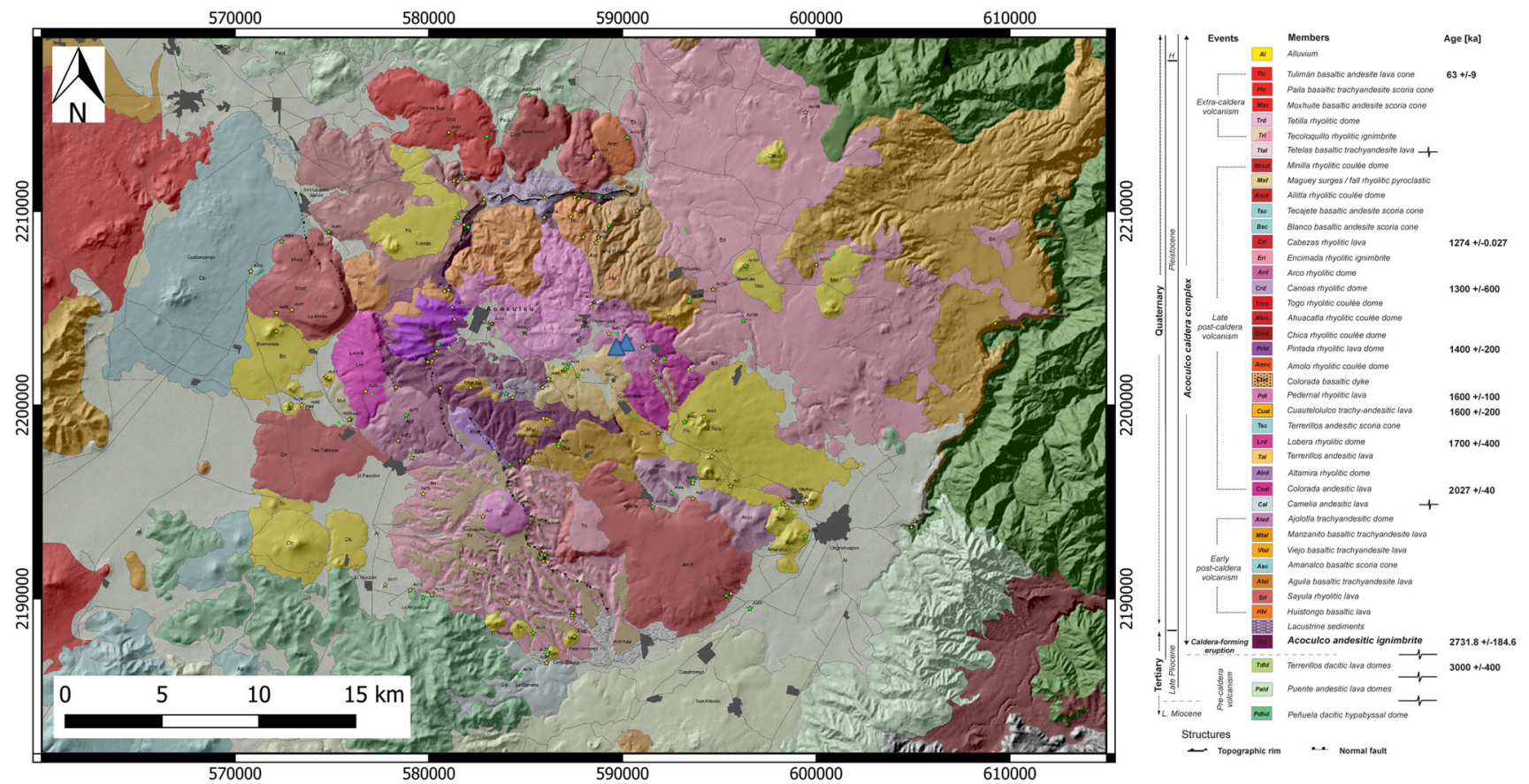

Figure 4. Geological map of Acoculco adapted from Avellán et al. (2018a). Blue triangles: location of the two wells used for modelling. Coordinate system is WGS84/UTM zone 14N.

Los Humeros). This is why in Acoculco it is more important to separate the basement into four lithological groups (Cretaceous limestone, granite, metamorphic rock such as hornfels and skarn, and marble) and group all volcanic products in a single body.

\section{Methodology}

The GEMex project aims at integrating all contributions from the various disciplines involved in geothermal exploration in cooperative 3-D geomodels (Calcagno, 2015). To initiate the process, preliminary geological models were developed using the data and knowledge available at the start of the project. 


\subsection{Workflow}

Construction of the geological models followed the five main steps described below. They were completed in a collaborative manner described in Sect. 3.3.

\subsubsection{Bounding box}

Both the Los Humeros and Acoculco sites were modelled at a regional scale (Fig. 1). The horizontal dimensions of the regional models are those the areas of the geological maps presented above. This scale is appropriate for studying the processes driving geothermal systems. In addition, a localscale model was constructed for Los Humeros, focusing on the existing exploitation area and dedicated to studying the geothermal reservoir. Both regional models roughly cover the same surface area. The depth extension is the same for all three models.

\subsubsection{Digital Elevation Model}

Digital Elevation Models (DEMs) were provided by the Instituto Nacional de Estadística y Geografía (INEGI, Mexico). They give the altitude of the topography (a.s.l.) at the nodes of a 2-D grid. The resolution, i.e. the distance between two adjacent nodes, is the same along the east-west and northsouth axes, but depends on the model (see Sect. 4, hereafter). The upper part of the geological model is limited by the DEM surface.

\subsubsection{Faults}

A selection of the faults to be modelled was made to keep only those that are representative of the area at the scale of the model, and considering the geothermal objective of the project. They were combined into fault networks to manage their topology, i.e. to decide which one is the master fault where two faults intersect. Faults and networks are described in further detail in Sect. 4.1 and 4.2.

Almost no data are available for the fault geometry at depth. To give them a realistic geological shape, it was thus assumed that their vertical extension depends upon their surface extension, i.e. the longer a fault extends on surface, the deeper it will be.

Considering the measured geothermal gradient (about $100{ }^{\circ} \mathrm{C} \mathrm{km}^{-1}$, López-Hernández et al., 2009; Lorenzo-Pulido et al., 2010) and assuming a continental crust mechanically controlled by the rheological behaviour of quartz, a brittle/ductile transition was interpreted to occur at 4 to $4.5 \mathrm{~km}$ below ground level for both sites. Faults are only modelled in the brittle zone and are thus limited at depth by the brittle/ductile transition.

\subsubsection{Formations}

The geological formations were selected to be representative of the area at the scale of the model, considering the geothermal objective of the project. The four regional groups and nine local units considered in Los Humeros, and the five groups in Acoculco are described in Sect. 2, above.

\subsubsection{Geological data}

Three types of data describing the geology were used for constraining the 3-D models presented here. They come from the literature available at the start of the project and some preliminary fieldwork at Acoculco. Geological maps, cross sections and well logs were redrawn for providing coherent data on the faults and formations selected for the modelling.

The geological maps of the sites were the main references for creating the preliminary models (Figs. 2 and 4). The reinterpreted geological maps for Los Humeros are shown on Figs. 5 and 6, respectively at regional and local scales, and on Fig. 7 for Acoculco at a regional scale.

For Los Humeros, existing cross sections were used to constrain the models at depth (Fig. 8). As for the geological maps, the cross sections were re-interpreted to fit the selected faults and formations to be modelled.

The last sources of data are the well logs provided by the CFE, sixteen for Los Humeros (locations on Fig. 2) and two for Acoculco (locations on Fig. 4). They were reinterpreted in terms of the geological formations of the model, and provided valuable information at depth for constraining the 3-D models.

\subsection{3-D Modelling methodology}

The interpolation method uses two types of data: contact points and orientation data. The contact points are 3-D points located on the geological interface to be modelled, and orientation data are 3-D vectors showing the dip of this geological interface. Such an interface can be either a boundary between formations, or a fault surface. Contact points and orientation data were derived from the geological maps, cross sections, and well $\operatorname{logs}$ available for Los Humeros and Acoculco, before interpolation via a co-kriging geostatistical method (Lajaunie et al., 1997).

The result of the interpolation is a 3-D scalar potential field where isovalues represent geological interfaces (Lajaunie et al., 1997). A geological pile describes the chronological and topological relations between the geological formations. It allows automatic management of the contacts between formations (gradual or erosional). The links between faults and formations are also described in the modelling process, to compute automatically how faults affect formations. When faults interact with each other, they are combined in a fault network for describing their relations. 


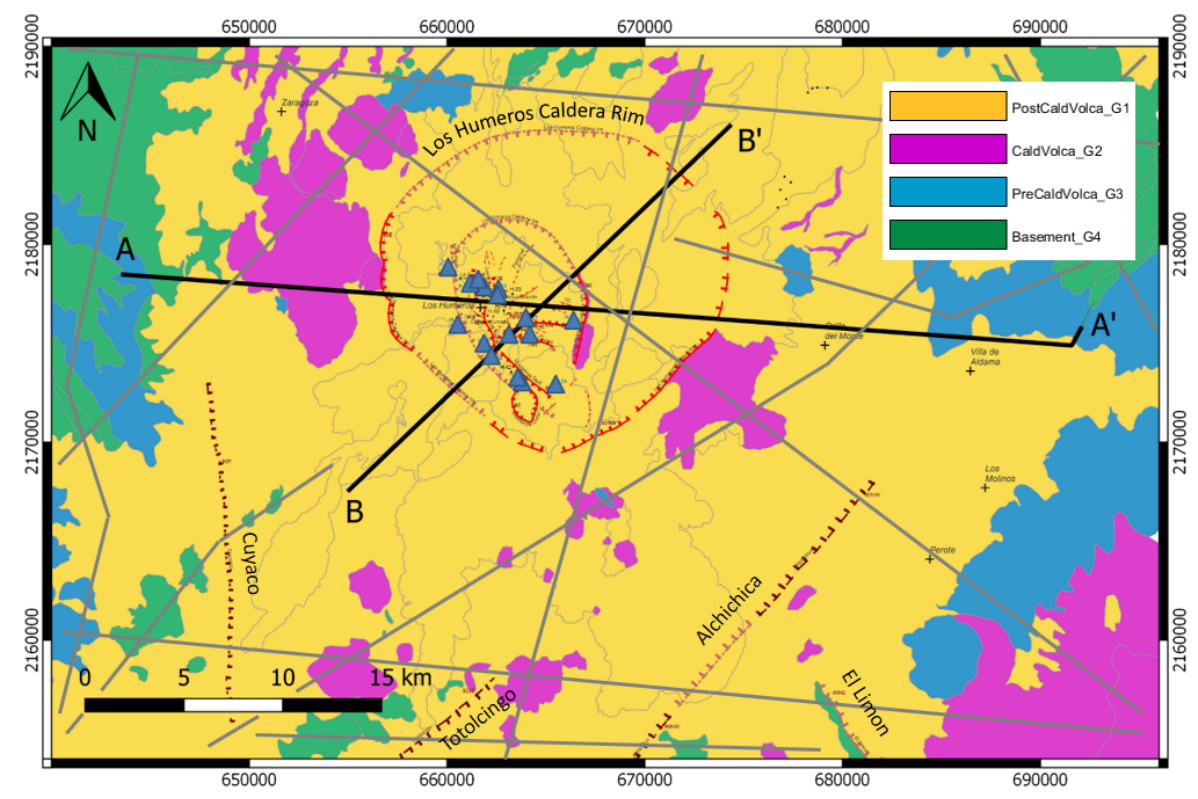

Figure 5. Los Humeros geological map reinterpreted from Carrasco-Núñez et al. (2017b) using the four groups selected for the regional scale modelling. Blue triangles: location of the sixteen wells used for modelling. AA': Carrasco-Núñez et al. (2017a) cross-section trace, BB': Norini et al. (2015) cross-section trace (see Fig. 8). Dark grey traces: additional cross-sections interpreted for constraining the model. Coordinate system is WGS84/UTM zone $14 \mathrm{~N}$.

This methodology is fully described in Calcagno et al. (2008) and implemented in the 3-D GeoModeller ${ }^{2}$ package.

\subsection{Collaborative working method}

One of the main outcomes of constructing a geological model is a coherent interpretation in three dimensions. Merging the data in the same 3-D space allows checking and correcting possible inconsistencies. Moreover, being able to visualize and to easily interact with the modelled geological objects is a powerful way of sharing a common view of the geology among a group of persons. The modelling process can then be used as a collaborative platform for exchange and debate, and for agreeing upon the geological interpretation.

Usually, a geomodel cannot be properly constructed by a single person, as such work not only relies on the merging of data, but also on integrating multiple knowledge sources and interpretations. The Los Humeros and Acoculco geomodels thus were constructed as a collaborative effort. Two teams, one dedicated to Los Humeros and the other to Acoculco, were created by scientists from Europe and Mexico. Team members included volcanologists, structural geologists and modellers; one geologist, a specialist of the area, acted as consultant and advisor for interpretation by each team.

\footnotetext{
23-D GeoModeller is a commercial software developed by BRGM and Intrepid Geophysics. For further information, please refer to Calcagno et al. (2008) and Guillen et al. (2008), and visit: https://www.geomodeller.com (last access: 22 October 2018).
}

The geological and geothermal settings of Los Humeros and Acoculco are quite different as described above. The rationale behind the construction of the geological models considered these different contexts. In addition, particular attention was paid to ensure a coherent geological interpretation of both areas, especially when similar geological objects were present in both sites.

Considering the international mix of scientists in the teams, a critical issue of the collaboration resides in communication. In order to render the collaborative process as efficient as possible, regular tele-workshops dedicated to working sessions based on interactive exchanges were organized. Furthermore, protocols such as the use of pdf 3-D files were set up for exchanging the 3-D models, allowing the team members to visualize and check the steps of the construction.

\section{The 3-D Geomodels}

The preliminary models presented in this paper are a coherent geometrical interpretation of the main geological objects, modelled from all available data and knowledge. They were developed following the methodology described in Sect. 3

\subsection{Los Humeros}

A 90 and 30 m-resolution DEM were used for the regional and local models, respectively. The geological map was reinterpreted from Carrasco-Núñez et al. (2017b); see Fig. 2 for the original map, and Figs. 5 and 6 for the re-interpreted 


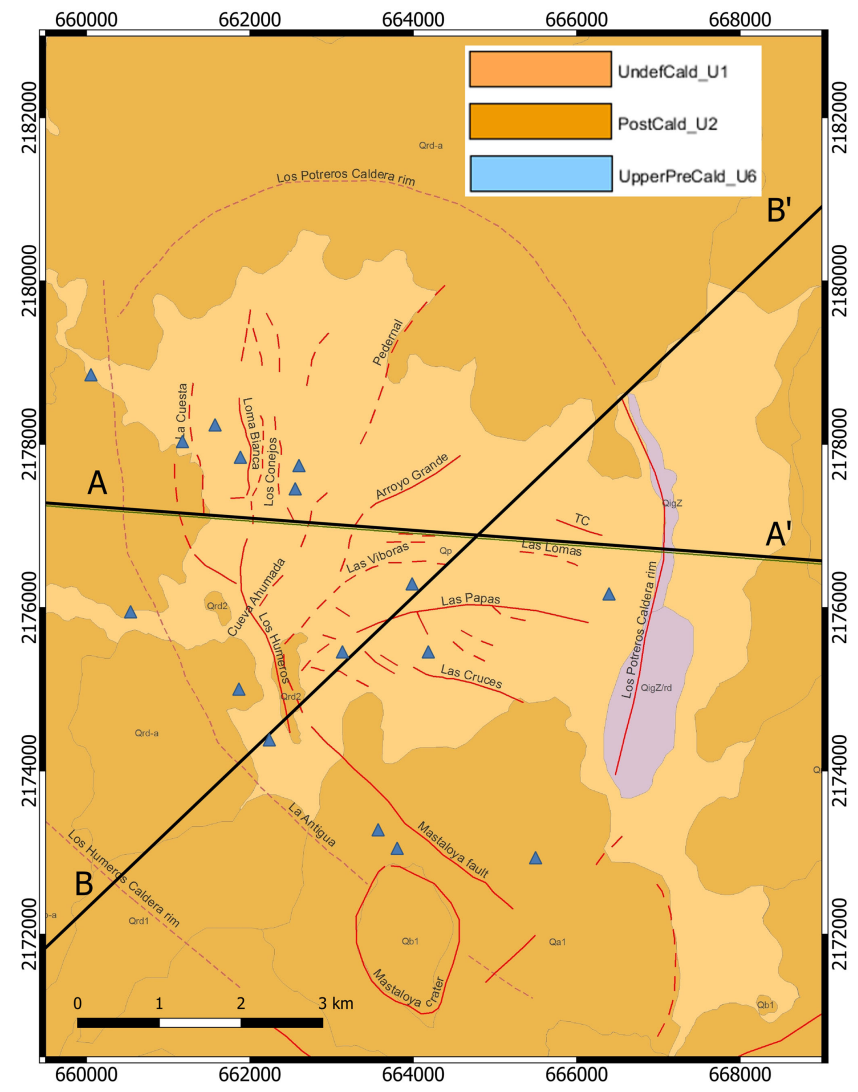

Figure 6. Los Humeros geological map reinterpreted from Carrasco-Núñez et al. (2017b) using the nine units selected for local scale modelling. Blue triangles: location of the sixteen wells used for modelling. AA': Carrasco-Núñez et al. (2017a) cross-section, BB': Norini et al. (2015) cross-section (see Fig. 8). Coordinate system is WGS84/UTM zone $14 \mathrm{~N}$.

ones, respectively at regional and local scales. Moreover, two geological sections are adapted from Carrasco-Núñez et al. (2017a) and Norini et al. (2015) (Fig. 8). These geological maps and cross sections were the main references for developing the preliminary models. The selected main faults for modelling at the regional and local scale (see Sect. 4.1.1 and 4.1.2, above), all had a maximum depth extension corresponding to the interpreted brittle-ductile transition zone. The geological logs of sixteen wells were provided by the CFE (Fig. 2). Considering the lack of information available on their geometry, the wells were considered to be vertical.

The thirty-four formations described on the recent geological map by Carrasco-Núñez et al. (2017b) were reinterpreted to fit the geological formations selected at regional and local scales (Fig. 3). The reference cross-sections (Carrasco-Núñez et al., 2017a; Norini et al., 2015), and the well $\operatorname{logs}$ then were re-interpreted accordingly.

Detailed technical descriptions are available in Evanno (2017).

\subsubsection{Regional scale}

The Los Humeros regional-scale model covers a block of $56 \times 36 \times 12 \mathrm{~km}$ (i.e. down to $7 \mathrm{~km}$ b.s.l.). Twelve faults were modelled inside the Los Humeros caldera rim, the four other faults outside deriving from López-Hernández et al. (1995) (Fig. 9). The Los Humeros caldera rim was modelled as a single closed shape delimiting the main volcanic structure.

The modelled regional faults are: (1) Alchichica, (2) AntiguaFault, (3) CuevaAhumada, (4) Cuyuaco, (5) ElLimonFault, (6) LHCaldRim, (7) LHumerosFault, (8) LPotrerosCald, (9) LaCuesta, (10) LasCruces, (11) LasPapas, (12) LasViboras, (13) LosConejos, (14) MastaloyaCrater, (15) MastaloyaFault, (16) Totolcingo. They belong to a fault network where: (3), (7), (9), (12), and (15) stop on (2).

The four groups of formations: pre-volcanic basement, pre-caldera volcanism, caldera stage, and post-caldera volcanism, were added to the fault model to complete the geological model (Fig. 10). In addition to the existing data (map, two reference cross-sections, sixteen well $\operatorname{logs}$ ) and where needed, eleven more cross-sections were interpreted for input into the model (see traces on Fig. 5). These were drawn according to the two reference cross-sections cited above, to ensure a coherent 3-D interpretation, especially regarding formation thickness.

\subsubsection{Local scale}

The local scale focuses on the exploited area within the Los Humeros caldera rim. The model was developed over a block of $9.5 \times 12.5 \times 12 \mathrm{~km}$ (i.e. down to $7 \mathrm{~km}$ b.s.l.) block. At this scale, structures and geological formations are more detailed than in the regional area. In particular, a network of seventeen faults structures the area (Fig. 11).

The modelled faults at the local scale are: (2) AntiguaFault, (3) CuevaAhumada, (6) LHCaldRim, (7) LHumerosFault, (8) LPotrerosCald, (9) LaCuesta, (10) LasCruces, (11) LasPapas, (12) LasViboras, (13) LosConejos, (14) MastaloyaCrater, (15) MastaloyaFault, (17) ArroyoGrande, (18) LPotrerosFault, (19) LasLomas, (20) LomaBlanca, (21) Pedernal. They belong to a fault network where: (7), (9), and (15) stop on (2); (13) stops on (3); (17) stops on (12); (2) stops on (14).

The area is located where the two reference cross-sections intersect. In addition, the sixteen wells are all located within the local frame. The data are quite well distributed in the area of the Los Humeros local geological model. Only one complementary cross section (see trace on Fig. 6) provides extra interpretation data for constraining the 3-D model. The geometry of the selected nine units is presented on Fig. 12. 


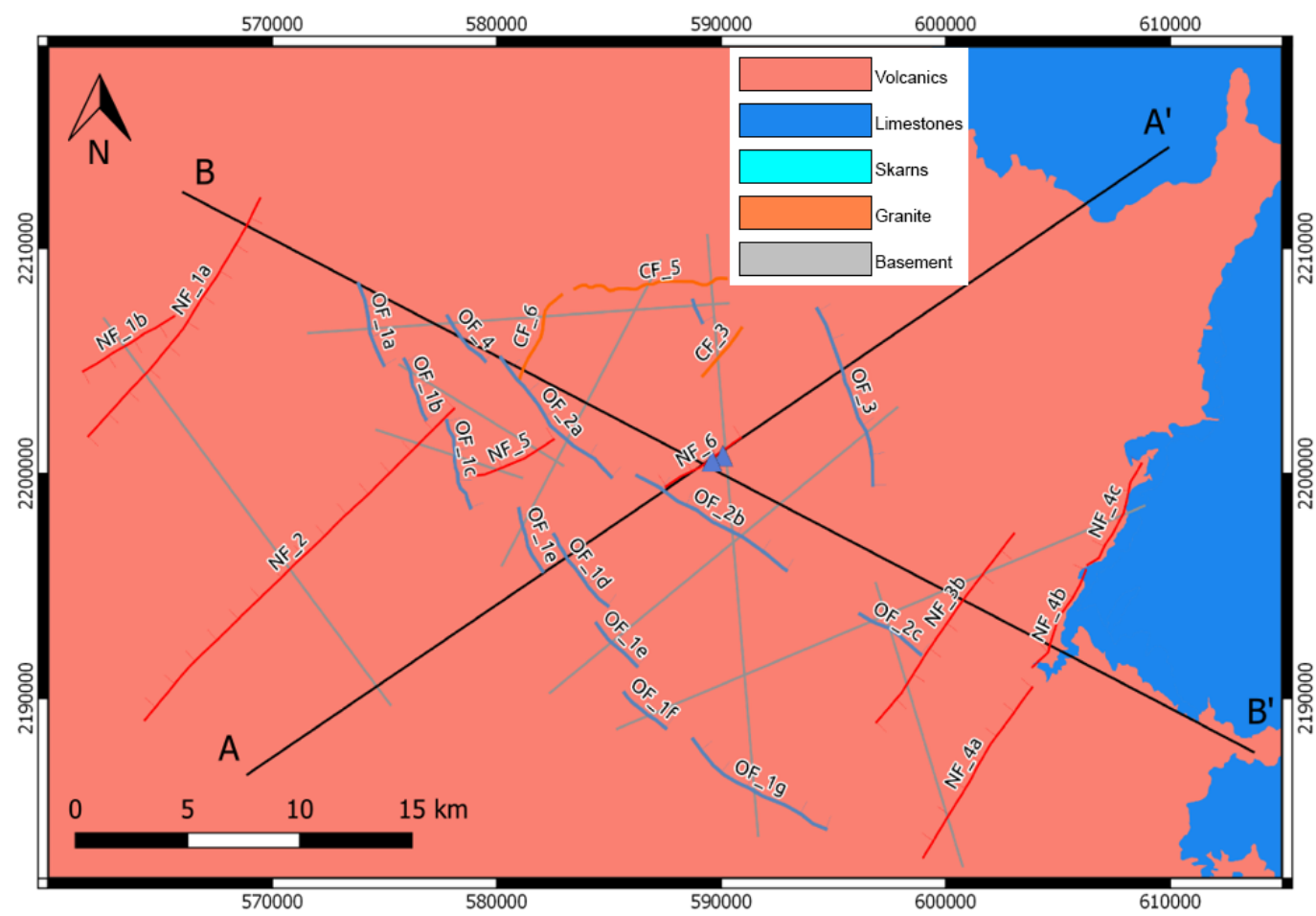

Figure 7. Acoculco geological map reinterpreted from Avellán et al. (2018a) using the five groups selected for the modelling. Blue triangles: location of the two wells used for modelling. Fault traces: normal faults (red), strike to oblique slip movement (blue), faults developed during the caldera collapse evolution (orange). AA' and BB': two main interpreted cross-sections (see Fig. 13). Dark grey trace: additional cross-section interpreted to constrain the model. Coordinate system is WGS84/UTM zone 14N.
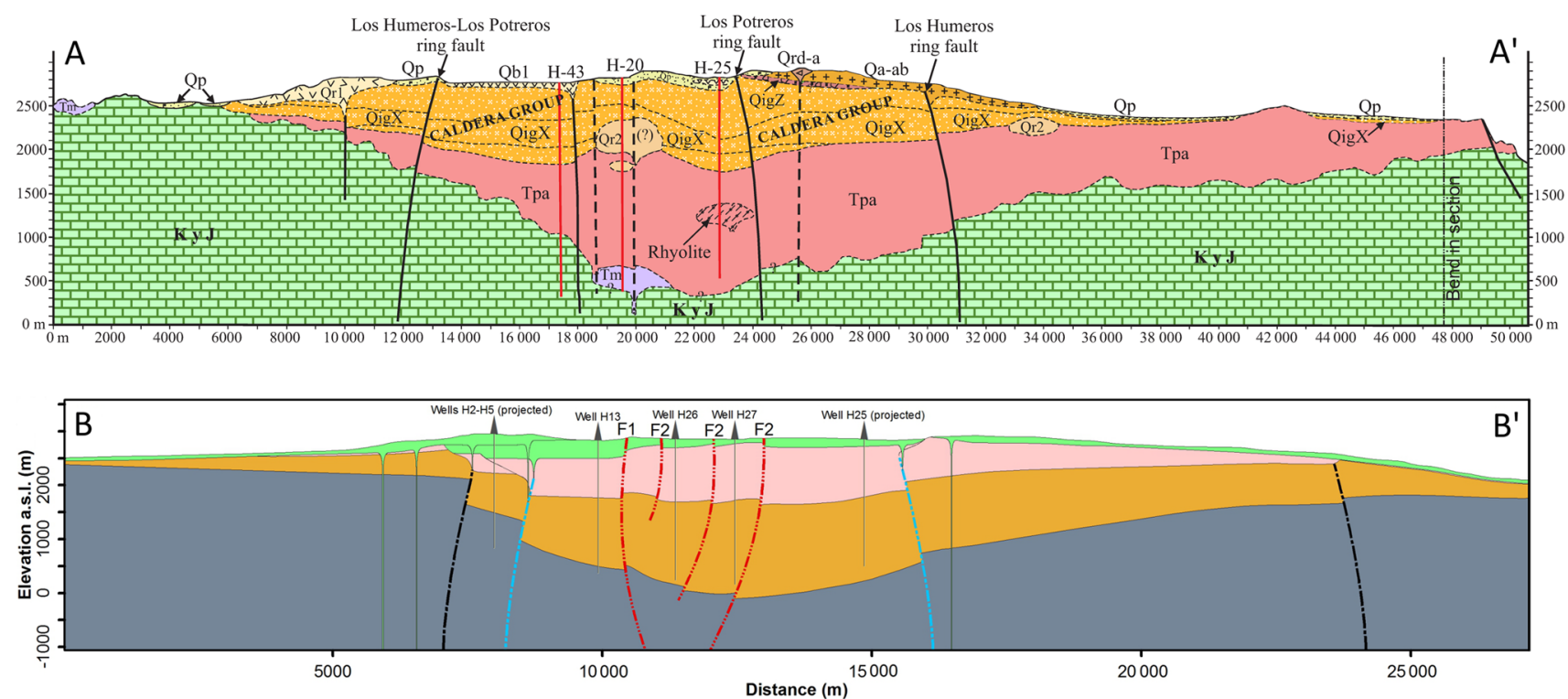

Figure 8. The two main cross-sections used for modelling the Los Humeros area. AA' from Carrasco-Núñez et al. (2017b). BB' from Norini et al. (2015). See Fig. 2 for location. 


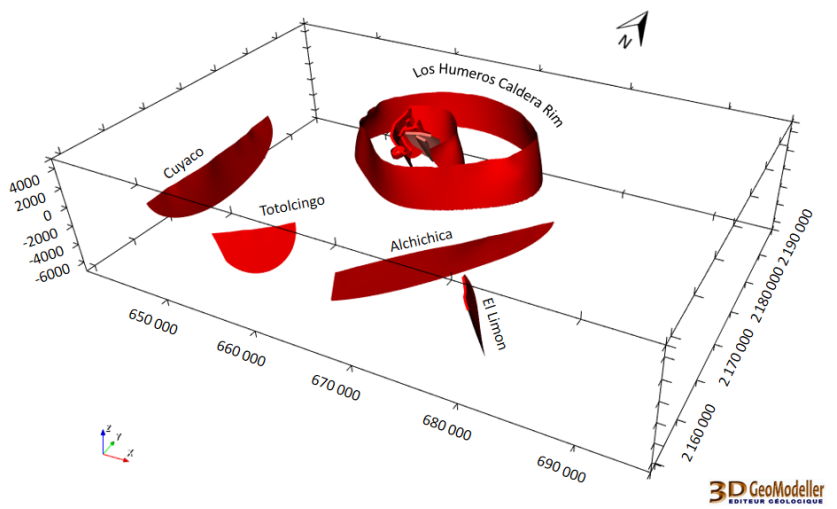

Figure 9. The Los Humeros regional fault model, including twelve faults inside the caldera rim and four outside. The latter are inferred by López-Hernández et al. (1995) with no field evidence. Coordinate system is WGS84/UTM zone 14N.

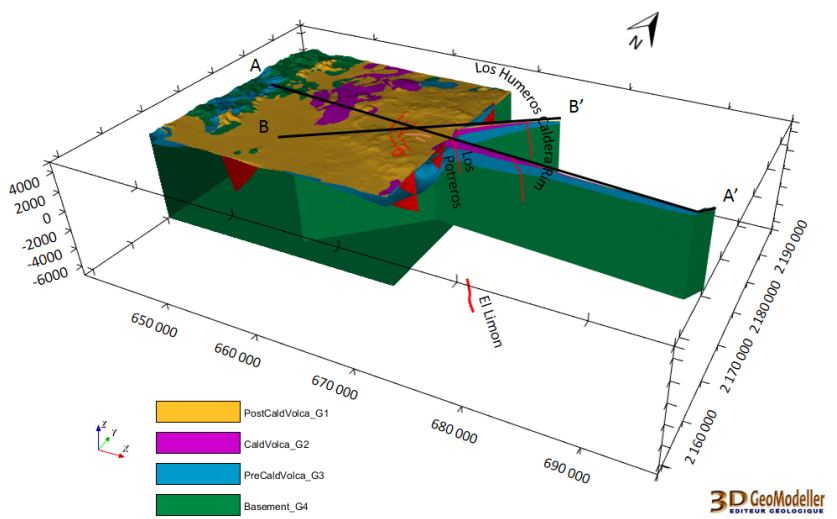

Figure 10. The Los Humeros regional geological model including the fault model (see 3DLHRegionalFaultModel) and the four geological groups listed at bottom left. AA': Carrasco-Núñez et al. (2017a) cross-section, BB': Norini et al. (2015) cross-section (see Fig. 8). Coordinate system is WGS84/UTM zone 14N.

\subsection{Acoculco}

The main reference for the Acoculco preliminary regional geomodel is the geological map by Avellán et al. (2018a) (Fig. 4); Fig. 7 shows the re-interpreted map. In addition, two geological cross-sections were drawn for highlighting the deep structures down to the brittle/ductile transition zone, estimated at about $4 \mathrm{~km}$ depth (below ground level) based on the thermal gradient (Fig. 13). Relevant data from the two wells available on the site were also taken into account, as were the available GEMex fieldwork data. A $15 \mathrm{~m}$ resolution DEM was used for the modelling. Nine supplementary cross-sections (see traces on Fig. 7) were interpreted to better constrain and guarantee a consistent 3-D understanding of the relationship between faults and formations.

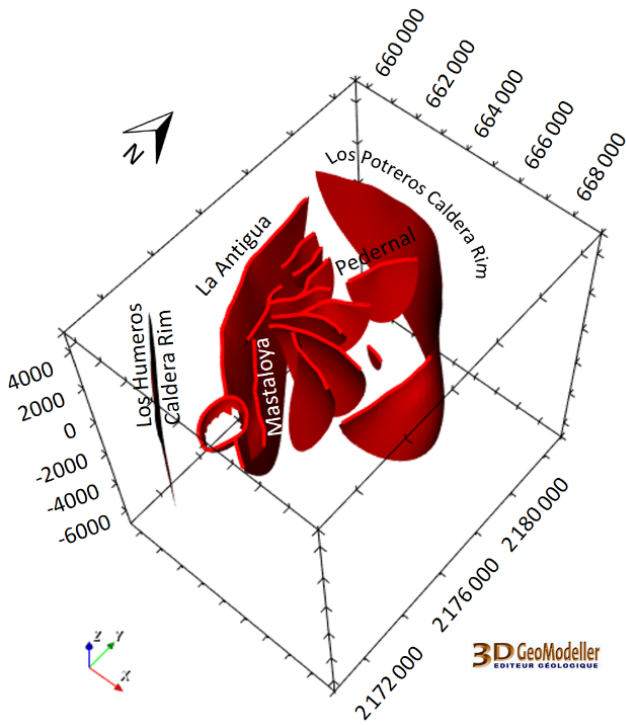

Figure 11. Seventeen faults are interpreted in the Los Humeros local fault model. Coordinate system is WGS84/UTM zone $14 \mathrm{~N}$.

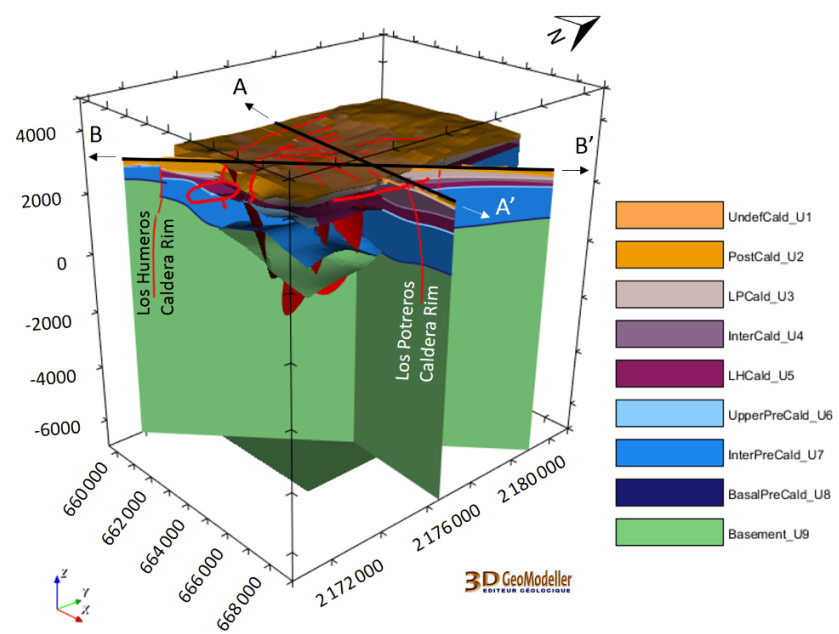

Figure 12. The Los Humeros local geological model. Fault traces are in red (see Fig. 6). Nine geological units are modelled. AA': Carrasco-Núñez et al. (2017a) cross-section, BB': Norini et al. (2015) cross-section (see Fig. 8). Coordinate system is WGS84/UTM zone 14N.

The model covers a $56 \times 37 \times 10.5 \mathrm{~km}$ block (i.e. down to $7 \mathrm{~km}$ b.s.l.). Twenty-six fault segments were introduced into the geological model, the fault network being based on the recent geological map by Avellàn et al. (2018a) and the fieldwork done during the first stage of GEMex project (Fig. 14).

The modelled faults are: (a) NF_1a, (b) NF_1b, (c) NF_2, (d) NF_3b, (e) NF_4a, (f) NF_4b, (g) NF_4c, (h) NF_5, (i) NF_6, (j) OF_1a, (k) OF_1b, (l) OF_1c, (m) OF_1d, (n) OF_1e, (o) OF_1f, (p) OF_1g, (q) OF_1h, (r) OF_2a, (s) OF_2b, (t) OF_2c, (u) OF_3, (v) OF_4, (w) OF_5, 
(x) CF_3, (y) CF_5, (z) CF_6. They belong to a fault network where: (b) stops on (a); (c) stops on (l); (h) stops on (l) and (r); (i) stops on (s); (t) stops on (d); (y) stops on (z); (z) stops on (r).

Five groups of rocks were modelled. The basement, which is the planned geothermal target at Acoculco, was split into four groups while all the overlying volcanic rocks were gathered in a single group. The basement includes, from bottom to top, phyllite and micaschist, and limestone and skarn, intruded by a granite (Fig. 15).

\section{Discussion}

The work described here initially was mainly based on existing bibliographic and map data. This meant that some geological objects were weakly constrained, especially far from the wells and at depth. The preliminary results presented here are thus partly based on the interpretations by experts of the modelled areas. However, the closely collaborative work between the European and Mexican partners enhanced the robustness and reliability of these interpretations.

\subsection{Los Humeros}

CFE (Comisión Federal de Electricidad, Mexico) provided detailed lithological descriptions of the rocks intersected by each of the 16 geothermal wells used for constructing the local 3-D model of Los Humeros. Most of those descriptions were made by CFE geologists from cuttings obtained during well drilling, which were further analysed under the microscope. This produced a very detailed and varying lithology that was useful for CFE, but impractical for modelling purposes. Thus, it was necessary to regroup all lithological variations into nine lithological units for the local model.

However, in some wells it was difficult to assign some parts of the lithological columns defined by the experts from CFE to one of those nine lithological units. That led to uncertain lithological correlations in the local model between some wells. This issue will be re-examined in the next stages of the project, especially when data from 35 additional wells will be provided by CFE.

Isotopic studies, carried out for the GEMex project to compare geothermal fluids and water from springs around Los Humeros, suggest that the recharge area of the geothermal system is of regional scale, in addition to local recharge inside the caldera area. This implies that regional structures channelling meteoric water are necessary for maintaining the geothermal system. However, the preliminary Los Humeros models show no connection between regional and local structures, and more work will be necessary for ascertaining that pathways exist between the outer and inner parts of the Los Humeros caldera.

In Los Humeros, the regional and the local models were dedicated to investigating scale-related processes. Large structures or the recharge of the geothermal system were evaluated at a regional scale, while understanding of the exploited reservoir requires a local-scale examination. In addition, the two scales are complementary; studies carried out at the regional scale provide boundary conditions for the localscale work. For instance, local-scale reservoir modelling, benefits from the hydrogeological simulation at a regional scale.

\subsection{Acoculco}

The preliminary model is the basis for further work around the two existing boreholes, i.e. the evaluation of EGS feasibility. In Acoculco, the volcanic formations range from Late Miocene to Present. Their evolution took place within the same stress field, unchanged over time (Avellán et al., 2018a). This also provided the setting that created the volcano and caldera.

The Acoculco area is intersected by NNW-SSE and NESW to ENE-WSW fault systems in mutual cross-cut relations, which suggests their contemporaneity. The faults belong to three different groups in terms of geometry and kinematics (see Fig. 7). The first group includes mainly ENEWSW oriented normal faults. The second group comprises NNW-SSE faults with a typical strike- to oblique-slip movement. The last group concerns the caldera-rim faults, developed during caldera collapse.

The two exploration boreholes in Acoculco intersected a granite intrusion at about $1600 \mathrm{~m}$ depth, whose extension is unknown and whose geometry in the 3-D model must be considered as indicative only. However, the existing thermal anomaly cannot be related to such an intrusion, indicating that the magmatic source should be much deeper.

The Acoculco preliminary model will be refined with the help of new data obtained from the reprocessing of old geophysical Vertical Electrical Sounding (VES) and Transient ElectroMagnetic (TEM) data, the new planned fieldwork, and from the ongoing geophysical MagnetoTelluric (MT) and gravity surveys.

\section{Conclusions}

As part of the GEMex project, three preliminary geological models were constructed: a regional and a local one for Los Humeros, and a regional one for Acoculco. These models consist in a primary 3-D interpretation of the main geological objects, based on existing data and knowledge. Each model was set up - considering the scale it represents and the specific context of the site - to provide a continuous and coherent geometry of the selected faults and geological formations.

The numeric versions of the preliminary models are used as input for computations that require a quantified geometrical framework. The 3-D geological models are meshed 

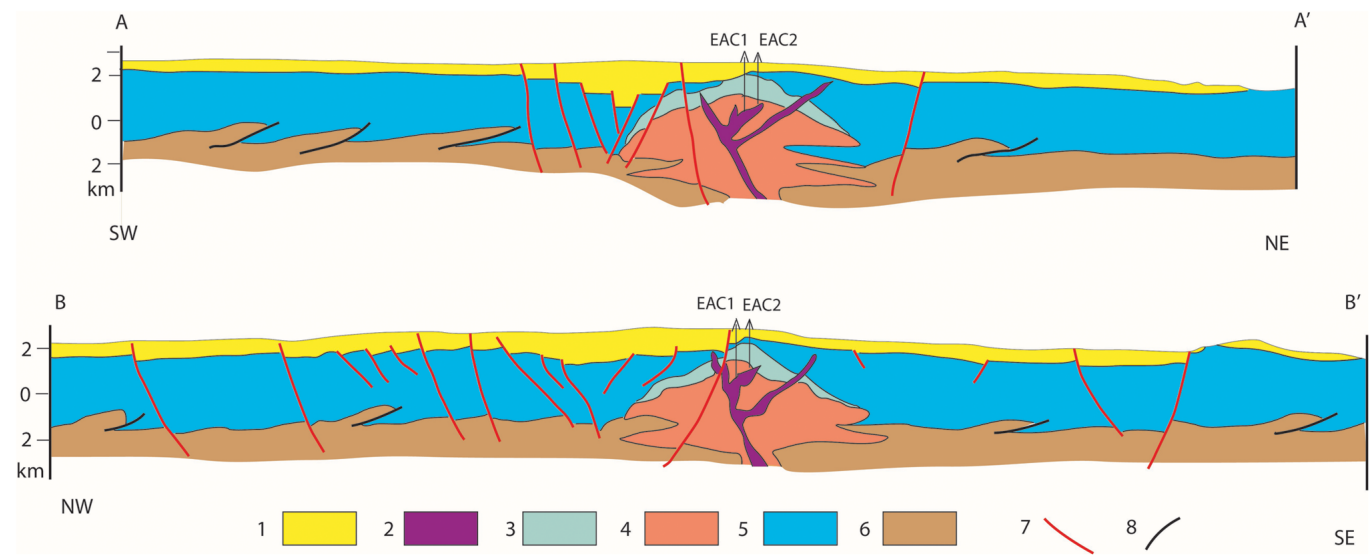

Figure 13. The two main cross-sections used for modelling the Acoculco area, see Fig. 7. Symbols: 1 - vulcanite (Pliocene-Holocene); 2 - Quaternary dyke; 3 - skarn and marble; 4 - crust involved in thermal anomalies through time: magma chambers originating the different volcanic events are supposed to be developed within this volume; 5 - Jurassic-Cretaceous limestone; 6 - crystalline rocks, mainly phyllite (Paleozoic); 7 - Neogene-Quaternary normal to oblique slip faults; 8 - thrust faults related to the Laramide orogenesis (Oligocene).

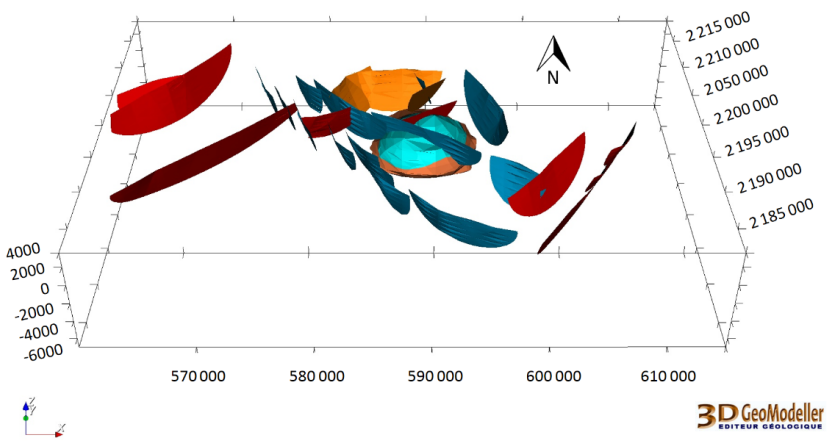

Figure 14. The Acoculco regional fault model. Twenty-six faults are modelled. Coordinate system is WGS84/UTM zone $14 \mathrm{~N}$.

and exported to feed third-party studies dedicated to thermal modelling (Bonté et al., 2018), fluid-flow simulation (Montegrossi, 2018), hydrogeological simulation, seismic-data analysis, and geophysical inversion.

The next step will involve enhancing the preliminary models with new data that are being acquired within GEMex, e.g. new borehole logs, geological fieldwork, geophysical surveys (e.g. Arzate et al., 2018), and geochemical measurements. They will provide additional constraints for strengthening the models, especially at depth. The methodology presented in this paper, including workflow indications and the collaborative way of working, is to be further developed for the forthcoming work within the project. The project as a whole is also a good candidate for carrying out similar future studies beyond the GEMex setting.

Data availability. The terms of the H2020 GEMex Grant Agreement restrict the use of the preliminary models to the partners of the

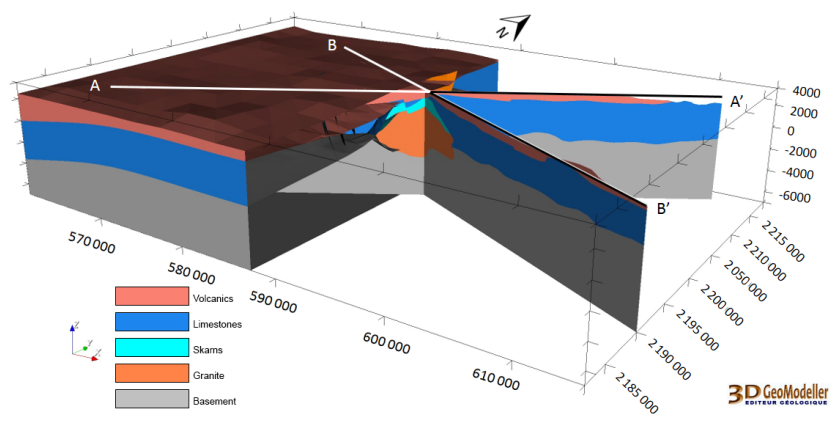

Figure 15. The Acoculco regional geological model. Five groups of geological formations are modelled from the geological map and two wells (Fig. 7), and the two main interpreted cross-sections AA' and BB' (see Fig. 13). Coordinate system is WGS84/UTM zone $14 \mathrm{~N}$.

project. Consequently, the data and results described in this paper are not available outside the GEMex consortium.

Author contributions. A collegial team coordinated by PC did the work presented in this paper. GE and GCN mainly worked on the Los Humeros site models. ET, JLM, and DL mainly worked on the Acoculco site model. LCGN worked on both sites. All authors participated in the writing and approved the final manuscript.

Competing interests. The authors declare that they have no conflict of interest.

Special issue statement. This article is part of the special issue "European Geosciences Union General Assembly 2018, EGU Division 
Energy, Resources \& Environment (ERE)". It is a result of the EGU General Assembly 2018, Vienna, Austria, 8-13 April 2018.

Acknowledgements. The authors wish to thank the Comision Federal de Electricidad (CFE, Mexico) for their assistance and support. This paper presents results of the GEMex Project, funded by the European Union's Horizon 2020 research and innovation programme under grant agreement No. 727550, and by the Mexican Energy Sustainability Fund CONACYT-SENER, Project 2015-04-268074. More information can be found on the GEMex Website: http://www.gemex-h2020.eu. Thank you to the GEMex members who helped to produce the work presented in this paper. The authors also thank Guillermo Cisneros for his technical support. Huybert Marinus Kluijver edited the English version of this paper. The manuscript was significantly improved thanks to the contribution of the two reviewers.

Edited by: Kristen Mitchell

Reviewed by: Florian Wellmann and one anonymous referee

\section{References}

Arzate, J., Corbo, F., Norini, G., Carrasco-Núñez, G., Hernández, J., and Yustis, V.: The Los Humeros (Mexico) geothermal field model deduced from new geophysical and geological data, Geothermics, 71, 200-211, https://doi.org/10.1016/j.geothermics.2017.09.009, 2018.

Avellán, D. R., Macías, J. L., Layer, P. W., Cisneros, G., Sánchez-Núñez, J. M., Gómez-Vasconcelos, Pola, A., SosaCeballos, G., García-Tenorio, F., Reyes-Agustín, G., OsorioOcampo, S., García-Sánchez, L., Mendiola, F., Marti, J., López-Loera, H., and Benowitz, J.: Geology of the Late Pliocene - Pleistocene Acoculco caldera complex, eastern Trans-Mexican Volcanic Belt (México), J. Maps, in press, https://doi.org/10.1080/17445647.2018.153107, 2018a.

Avellán, D. R., Macías, J. L., Layer, P. W., Sosa-Ceballos, G., Cisneros-Máximo, G., Sánchez-Núñez, J. M., GómezVasconcelos, M. G., Marti, J., García-Tenorio, F., López-Loera, H., Pola, A., Reyes-Agustín, G., and Benowitz, J.: Volcanic stratigraphy and structural architecture of the Late PliocenePleistocene Acoculco Caldera Complex, north of Puebla (México), J. Volcanol. Geoth. Res., submitted, 2018b.

Blöcher, M. G., Zimmermann, G., Moeck, I., Brandt, W., Hassanzadegan, A., and Magri, F.: 3-D numerical modeling of hydrothermal processes during the lifetime of a deep geothermal reservoir, Geofluids, 10, 406-421, 2010.

Bonté, D., Limberger, J., Békési, E., Beekman, F., and van Wees, J. D.: Preliminary estimation of the thermal structure of the Acoculco-Los Humeros area, Mexico, European Geosciences Union General Assembly, EGU2018-16270, Vienna, Austria, 2018.

Calcagno, P.: 3-D GeoModelling for a Democratic Geothermal Interpretation, in: Proceedings of World Geothermal Congress 2015 (WGC2015), Melbourne, Australia, 7 pp., 2015.

Calcagno, P., Courrioux, G., Guillen, A., and Chilès, J. P.: Geological modelling from field data and geological knowledge, Part I-
Modelling method coupling 3-D potential-field interpolation and geological rules, Phys. Earth Planet. Int., 171, 147-157, 2008.

Calcagno, P., Baujard, C., Guillou-Frottier, L., Dagallier, A., and Genter, A.: Estimation of the deep geothermal potential within the Tertiary Limagne basin (French Massif Central): An integrated 3-D geological and thermal approach, Geothermics, 51, 496-508, 2014.

Canet, C., Hernández-Cruz, B., Jiménez-Franco, A., Pi, T., Peláez, B., Villanueva-Estrada, R. E, Alfonso, P., González-Partida, E., and Salinas, S.: Combining ammonium mapping and short-wave infrared (SWIR) reflectance spectroscopy to constrain a model of hydrothermal alteration for the Acoculco geothermal zone, Eastern Mexico, Geothermics, 53, 154-165, 2015.

Carrasco-Núñez, G., López-Martínez, M., Hernández, J., and Vargas, V.: Subsurface stratigraphy and its correlation with the surficial geology at Los Humeros geothermal field, eastern Trans-Mexican Volcanic Belt, Geothermics, 67, 1-17, https://doi.org/10.1016/j.geothermics.2017.01.001, 2017a.

Carrasco-Núñez, G., Hernández, J., De León, L., Dávila, P., Norini, G., Bernal, J. P., Jicha, B., Navarro, M., and López, P.: Geologic Map of Los Humeros volcanic complex and geothermal field, eastern Trans-Mexican Volcanic Belt, Terra Digitalis, 1, 1-11, https://doi.org/10.22201/igg.terradigitalis.2017.2.24, 2017b.

Carrasco-Núñez, G., Bernal, J. P., Dávila, P., Jicha, B., Giordano, G., and Hernández, J.: Reappraisal of Los Humeros volcanic complex by new U/Th zircon and 40Ar/39Ar dating: Implications for greater geothermal potential, Geochem. Geophy. Geosy., 19, 132-149, https://doi.org/10.1002/2017GC007044, 2018.

Cloetingh, S., van Wees, J. D., Ziegler, P. A., Lenkey, L., Beekman, F., Tesauro, M., Förster, A., Norden, B., Kaban, M., Hardebol, N., Bonté, D., Genter, A., Guillou-Frottier, L., Ter Voorde, M., Sokoutis, D., Willingshofer, E., Cornu, T., and Worum, G.: Lithosphere tectonics and thermomechanical properties: An integrated modelling approach for Enhanced Geothermal Systems exploration in Europe, Earth-Sci. Rev., 102, 159-206, 2010.

Elders, W. A., Friðleifsson, G. O., and Pálsson, B.: Iceland Deep Drilling Project: The first well, IDDP-1, drilled into Magma, Geothermics, 49, 1-128, 2014.

Evanno, G.: 3-D preliminary geological modelling of the Los Humeros geothermal area (Mexico), M.Sc. Thesis, ENAG/MFE088-GB-2017, 123 pp., 2017.

Ferrari, L., López-Martínez, M., Aguirre-Díaz, G., and CarrascoNúñez, G.: Space-time patterns of Cenozoic arc volcanism in Central Mexico: from the Sierra Madre Occidental to the Mexican Volcanic Belt, Geology, 27, 303-306, 1999.

Ferriz, H. and Mahood, G. A.: Eruption rates and compositional trends at Los Humeros Volcanic Center, Puebla, Mexico, J. Geophys. Res., 89, 8511-8524, 1984.

García-Palomo, A., Macías, J. L., Jiménez, A., Tolson, G., Mena, M., Sánchez-Núñez, J. M., Arce, J. L., Layer, P. W. Santoyo, M. A., and Lermo-Samaniego, J.: NW-SE Pliocene-Quaternary extension in the Apan-Acoculco region, eastern Trans-Mexican Volcanic Belt, J. Volcanol. Geoth. Res., 349, 240-255, 2017.

Garcia-Valles, M., Pi, T., Alfonso, P., Canet, C., Martínez, S., Jiménez-Franco, A., Tarrago, M., and Hernández-Cruz, B.: Kaolin from Acoculco (Puebla, Mexico) as raw material: Mineralogical and thermal characterization, Clay Miner., 50, 405-416, 2015. 
Guillen, A., Calcagno, P., Courrioux, G., Joly, A., and Ledru, P.: Geological modelling from field data and geological knowledge, Part II, Modelling validation using gravity and magnetic data inversion, Phys. Earth Planet. Int., 171, 158-169, 2018.

Houlding, S. W.: 3-D Geoscience Modeling; Computer Techniques for Geological Characterization, Springer-Verlag, Berlin, Germany, 1994.

Jolie, E., Bruhn, D., López Hernández, A., Liotta, D., GarduñoMonroy, V. H., Lelli, M., Hersir, G. P., Arango-Galván, C., Bonté, D., Calcagno, P., Deb, P., Clauser, C., Peters, E., Hernández Ochoa, A. F., Huenges, E., González Acevedo, Z. I., Kieling, K., Trumpy, E., Vargas, J., Gutiérrez-Negrín, L. C., AragónAguilar, A., Halldórsdóttir, S., González Partida, E., van Wees, J. D., Ramírez Montes, M. A., Diez León, H. D., and the GEMex team: GEMex - A Mexican-European Research Cooperation on Development of Superhot and Engineered Geothermal Systems. Proceedings, 43rd Workshop on Geothermal Reservoir Engineering, Stanford University, Stanford, CA, 2018.

Lajaunie, C., Courrioux, G., and Manuel, L.: Foliation fields and 3-D cartography in geology; principles of a method based on potential interpolation, Mathemat. Geol., 29, 571-584, 1997.

López-Hernández, A.: Estudio Regional Volcánico y Estructural del Campo Geotérmico de Los Humeros, Pue., México, Geotermia Revista Mexicana de Geoenergía, 11, 17-36, 1995.

López-Hernández, A., García-Estrada, G., Aguirre-Díaz, G., González-Partida, E., Palma-Guzmán, H., and Quijano-León, J. L.: Hydrothermal activity in the Tulancingo-Acoculco Caldera Complex, central Mexico: Exploratory studies, Geothermics, 38, 279-293, 2009.

Lorenzo-Pulido, C., Armenta-Flores, M., and Ramírez-Silva, G. Characterization of the Acoculco Geothermal Zone as a HDR System, GRC Transactions, 34, 369-372, 2010.

Mallet, J. L.: Geomodeling, Oxford University Press, Oxford, New York, 2002.

Montegrossi, G., Deb, P., Clauser, C., Diez, D., and Ramirez Montes, M. A.: Modeling of Los Humeros geothermal field: preliminary results, European Geosciences Union General Assembly, EGU2018-17600, Vienna, Austria, 2018.

Norini, G., Groppelli, G., Sulpizio, R., Carrasco-Núñez, G., DávilaHarris, P., Pellicioli, C., Zucca, F., and De Franco, R.: Structural analysis and thermal remote sensing of the Los Humeros Volcanic Complex: Implications for volcano structure and geothermal exploration, J. Volcanol. Geoth. Res., 301, 221-237, https://doi.org/10.1016/j.jvolgeores.2015.05.014, 2015.
Olasolo, P., Juárez, M. C., Morales, M. P., D’Amico, S., and Liarte, I. A.: Enhanced geothermal systems (EGS): A review, Renew. Sust. Energ. Rev., 56, 133-144, 2016.

Peiffer, L., Bernard-Romero, R., Mazot, A., Taran, Y.A., Guevara, M., and Santoyo, E.: Fluid geochemistry and soil gas fluxes (CO2-CH4-H2S) at a promissory Hot Dry Rock Geothermal System: The Acoculco caldera, Mexico. J. Volcanol. Geoth. Res., 284, 122-137, 2014.

Peiffer, L., Wanner, C., and Pan, L.: Numerical modeling of cold magmatic $\mathrm{CO} 2$ flux measurements for the exploration of hidden geothermal systems, J. Geophys. Res.-Sol. Ea., 120, 6856-6877, https://doi.org/10.1002/2015JB012258, 2015.

Reinsch, T., Dobson, P., Asanuma, H., Huenges, E., Poletto, F., and Sanjuan, B.: Utilizing supercritical geothermal systems: a review of past ventures and ongoing research activities, Geoth. Energ., 16, https://doi.org/10.1186/s40517-017-0075-y, 2017.

Romo-Jones, J. M., Gutiérrez-Negrín, L. C. A., Flores-Armenta, M., Del Valle, J. L., and García, A.: Mexico, in: 2017 Annual Report, IEA Geothermal, 66-72, available at: https://drive.google. com/file/d/1ztLlE5MFdLwSndR7iLmAkMXnQth4c86T/view, last access: 9 November 2018

Schilling, O., Sheldon, H. A., Reid, L. B., and Corbel, S.: Hydrothermal models of the Perth metropolitan area, Western Australia: implications for geothermal energy, Hydrogeological Journal, 21, 605-621, 2013.

Sosa-Ceballos, G., Macías, J. L., Avellán, D. R., SalazarHermenegildo, N., and Boijseauneau-López, M. E.: The Acoculco Caldera Complex magmas: genesis, evolution and relation with the Acoculco geothermal system, J. Volcanol. Geoth. Res., 358, 288-306, 2018.

Wu, Q., Xu, H., and Zou, X.: An effective method for 3-D geological modeling with multi-source data integration, Comput. Geosci., 31, 35-43, 2005. 